\title{
HYDROLOGY, GEOMORPHOLOGY, AND MANAGEMENT: IMPLICATIONS FOR SUSTAINABILITY OF NATIVE SOUTHWESTERN FISHES
}

\author{
John N. Rinne ${ }^{1}$
}

The southwestern region of the United States is characterized by a desert climate (Dunbier 1968; Green and Sellers 1964; Jaeger 1957) and a highly diverse and complex topography (Chronic 1983, 1987; Nations and Stump 1981). Woven into this rather harsh and highly variable climate and topography are disjunct and precious aquatic habitats (Rinne 1995), many of which contain a single or at best several species of native fishes (Rinne in press a, b). Superimposed upon climate, geology, topography, and hydrology has been a dramatic increase in human population and associated development of the region. Marked changes in the hydrology of the region have resulted from dams, diversions, and groundwater pumping to support the rapid development of the Southwest (Miller 1961; Minckley 1973; Rinne and Minckley 1991; Rinne in press b). These hydrologic changes and associated biological introductions of nonnative species (Rinne 1996; Rinne and Janisch 1995; Rinne et al. 1998) have imposed extensive negative impacts on the native fishes of the region. Currently, the native fish fauna is listed largely as threatened or endangered. Sustainability of this dwindling natural resource (Rinne and Minckley 1991) is intimately linked to the multiple and interacting factors listed above.

\section{HYDROLOGY}

Historically, rivers and streams in the Southwest have been subjected to "feast" and "famine" in terms of surface water habitat for fishes; this continues to the present. Feasts in the form of episodic flooding occur at random intervals as a result of either summer monsoon precipitation events (Green and Sellers 1964) or elevated spring runoff resulting from rain on snow events in the montane areas or rapid warming that results in flooding. In summer, these elevated flows often occur as "flash floods" such as illustrated by Rinne

\footnotetext{
${ }^{1}$ Rocky Mtn. Research Station, USDA Forest Service, Flagstaff
}

and Minckley (1991). Normally, these events subside very quickly. In contrast, rain on snow events or excessive rains in winter (February-March) also result in more sustained flood events in streams (Figure 1). Floods have been implicated in resorting and re-distributing substrate components and in providing optimum spawning habitat for native fishes (Rinne in press b). Disturbance in form of flooding also creates a greater diversity of aquatic habitats in streams and rivers (Figure 2) that, in turn, enhances native fish diversity.

It was first hypothesized by Meffe (1984), based on laboratory studies, that flooding could be more beneficial to native fishes than nonnatives. Later, Minckley and Meffe (1987) and Rinne and Stefferud (1997) supported this hypothesis based on data collected from naturally flowing environments. Rinne et al. (in press) and Rinne (in press c) demonstrated that differences in the flow regimes of rivers can result in markedly different fish species assemblages. That is, the Gila River headwaters experiences both more frequent and largervolume flood events than the Verde River headwaters. The former river sustains more native fishes than the latter, including two threatened cyprinid species, spikedace (Meda fulgida) and loach minnow (Rhinicththys cobitis).

The famine or drought component of Southwest hydrology can result in intermittency of streams and rivers or complete loss of surface waters (Rinne 2000). Intermittent flows can result in limited water quality for fishes in the form of elevated water temperatures and lowered dissolved oxygen; either singularly or in combination, these water quality variables can be lethal to desert fishes (Rinne et al. 2002). Lack of these flooding and drought conditions might be beneficial to nonnative species of fishes rather than natives (Rinne in press b). Stable, low flows during periods of drought enable nonnative fishes to establish and increase in abundance (Rinne 1999). In contrast, variable flow regimes accompanied by 


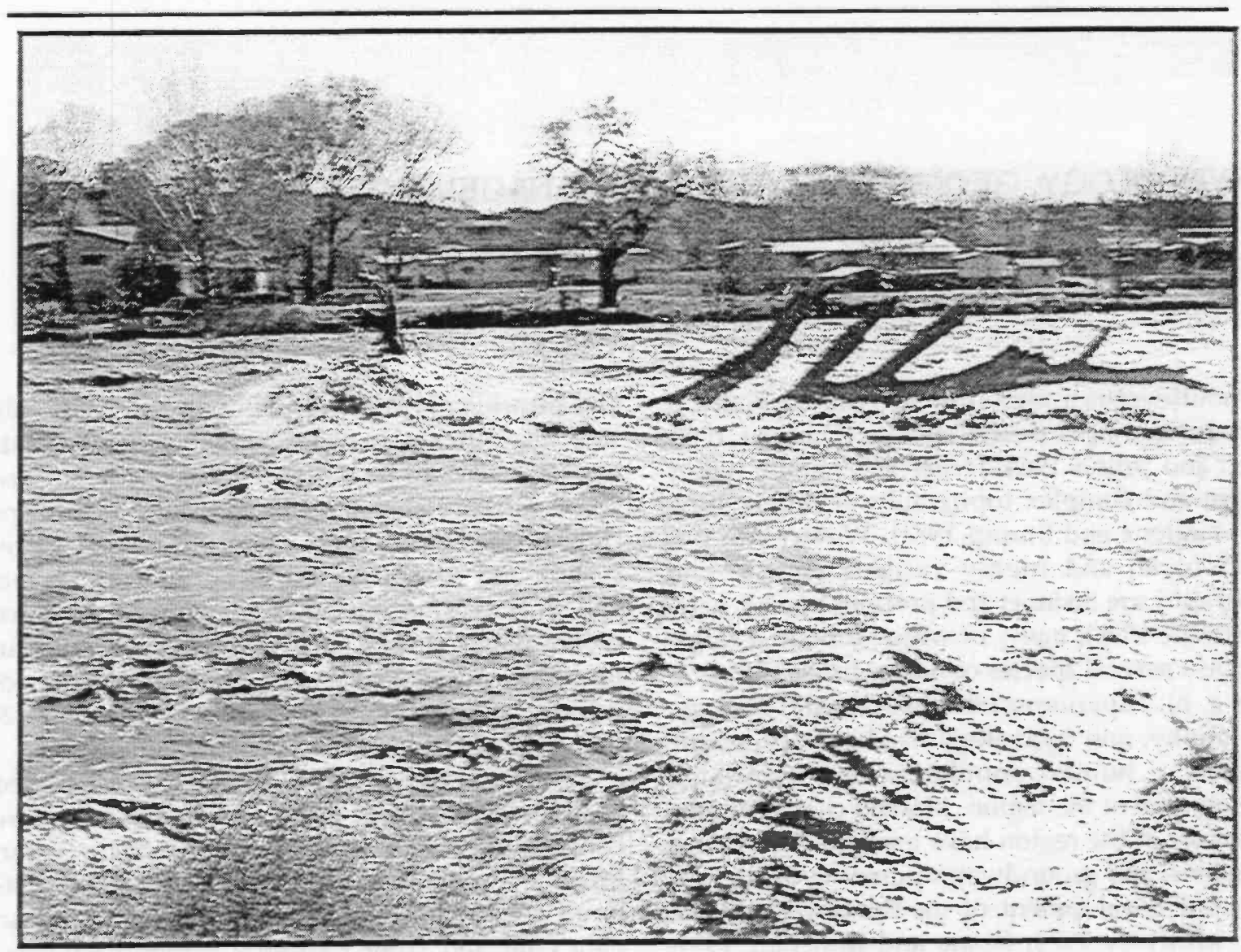

Figure 1. A large, 10-year sustained flood event in March of 1995 on the Verde River, Arizona. This flood event (and others historically) occur in winter (March-April) and result from extensive winter rains or rain on snow events in the Southwest.

periodic flooding reduce nonnative fish abundance and enhance that of native species (Rinne and Stefferud 1997).

\section{GEOMORPHOLOGY}

More than two decades ago, Platts (1979) suggested that geomorphology is an important, overriding determinant in fish community structure. Rinne (2000) documented that parent geology was very important in defining the abundance of salmonids in the White Mountains of east-central Arizona. Differing parent materials result in different stream substrates, some more optimum for Apache trout spawning (Rinne 2001a). Rinne (in press $b$ ) has suggested that there are two major geomorphic types of rivers: canyon bound and alluvial valleys (Figure 3). Based on fish assemblages in these two geomorphically different types of river reaches, native species generally predominate in the more broad alluvial valley reaches. In part, this is attributable to greater diversity of habitat, illustrated in Figure 2, resulting from flooding in these areas and a more broad flood plain for the flood event to create habitat diversity. Further, there are less deep $(>2 \mathrm{~m})$ pool habitats in the broad alluvial valleys compared to the river canyon reaches (Figure 2). Large, nonnative predators such as bass and catfish inhabit these deep pools and prey on native species (Rinne 2001b; Rinne et al. in press). By comparison, these nonnative predatory, pool-inhabiting species become greatly reduced in numbers in alluvial valley reaches where pools are fewer and shallower in depth. Relative distribution and abundance of the threatened spikedace and loach minnow in the upper Gila River (Table 1) further corroborate this hypothesis (Rinne et al. in press). Both diminish in abundance as one moves into these canyon reaches and then reappear and increase in abundance in reaches containing more optimum habitat (Rinne and Deason 2000) below and outside canyon-bound reaches. 


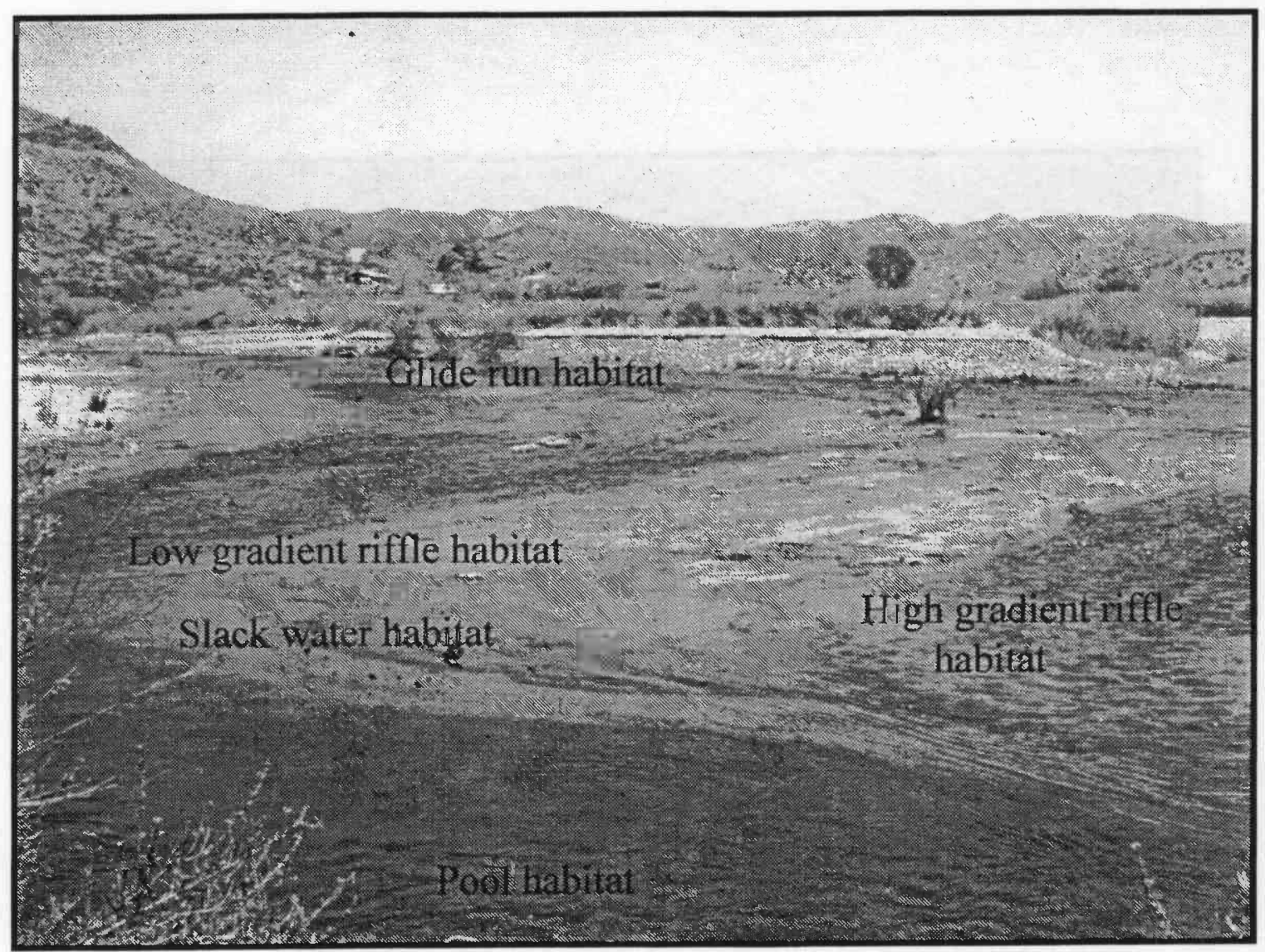

Figure 2. Diversity of habitat as illustrated here from the Gila River at Redrock, New Mexico results from flood events in alluvial valleys which result in D-type channels and greater diversity of aquatic habitats. These in turn increase fish diversity and abundance in specific reaches.

\section{MANAGEMENT}

Commencing in 1911 with completion of Roosevelt Dam on the Salt River northeast of Phoenix, Arizona, aquatic habitats in the Southwest have been increasingly and markedly altered by mainstream dams. The U.S. Bureau of Reclamation has constructed dozens of mainstream dams on southwestern rivers (Figure 4). These dams controlled flows, altered water quality, and dried up some rivers such as the Gila below San Carlos Reservoir (Rea 1983) and the Salt below Granite Reef Dam. In Arizona, Rinne (1994) calculated that 75 percent of

Table 1. Distribution and abundance of two threatened species in the upper Gila River relative to canyon-bound and alluvial valley reaches, 1999.

\begin{tabular}{llcc}
\hline \multicolumn{2}{l}{ Reach and Type } & Spikedace & Loach Minnow \\
\hline I & Both & 65 & 74 \\
II & Canyon bound & 0 & 0 \\
III & Canyon bound & 0 & 0 \\
IV & Alluvial valley & 750 & 104 \\
V & Both & 84 & 22 \\
\hline
\end{tabular}

mainstream river habitat has been lost through modification by dams alone; there have also been diversions for irrigation and groundwater pumping (Rinne and Minckley 1991; Rinne in press b). Some rivers, such as the upper Verde in Arizona, currently have a high probability of losing surface flow due to planned housing developments in the Chino Valley area (Neary and Rinne 2001; Wirt and Hjalmarson 2000). Water management to facilitate development in an arid, desert environment has had a major impact on native fishes in the area.

Accompanying the dramatic hydrologic management in the form of storage reservoirs behind major, mainstream dams has been widespread and intensive introduction of nonnative species of fishes, largely for sport fishing (Rinne in press a; Rinne and Janisch 1995; Rinne et al. 1998). In Arizona, more than 100 nonnative species have been introduced in the century of time between 1890 and 1990 (Rinne 1996; Rinne in press a). Almost half have become established in the waters of Arizona, resulting in a 100 percent increase in fish 

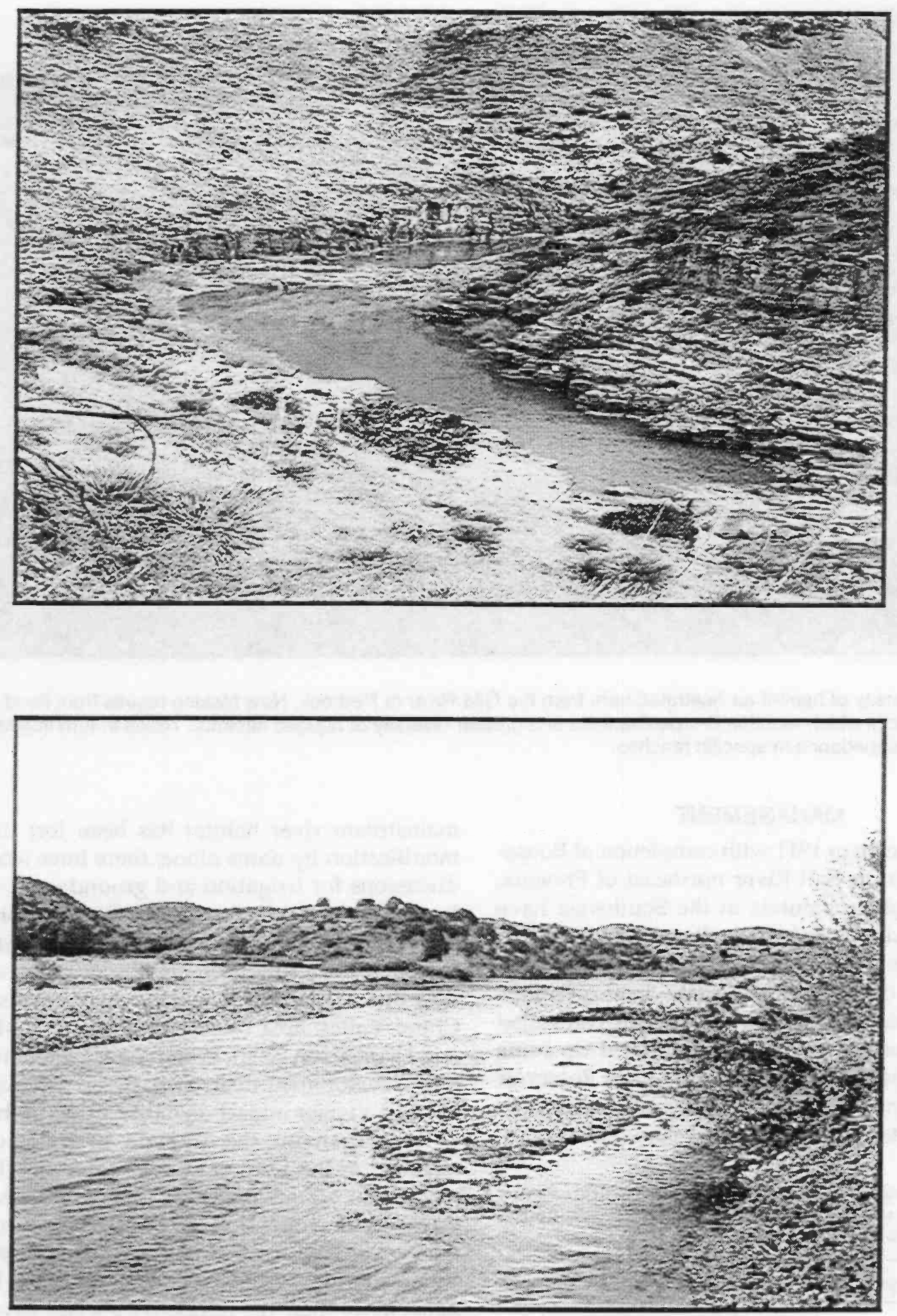

Figure 3. Southwestern rivers are encompassed by two types of geomorphic structuring: canyon bound (top, Salt River Canyon, northeast of Globe, Arizona) and wide alluvial valleys (bottom, Gila River below Cliff, New Mexico). 


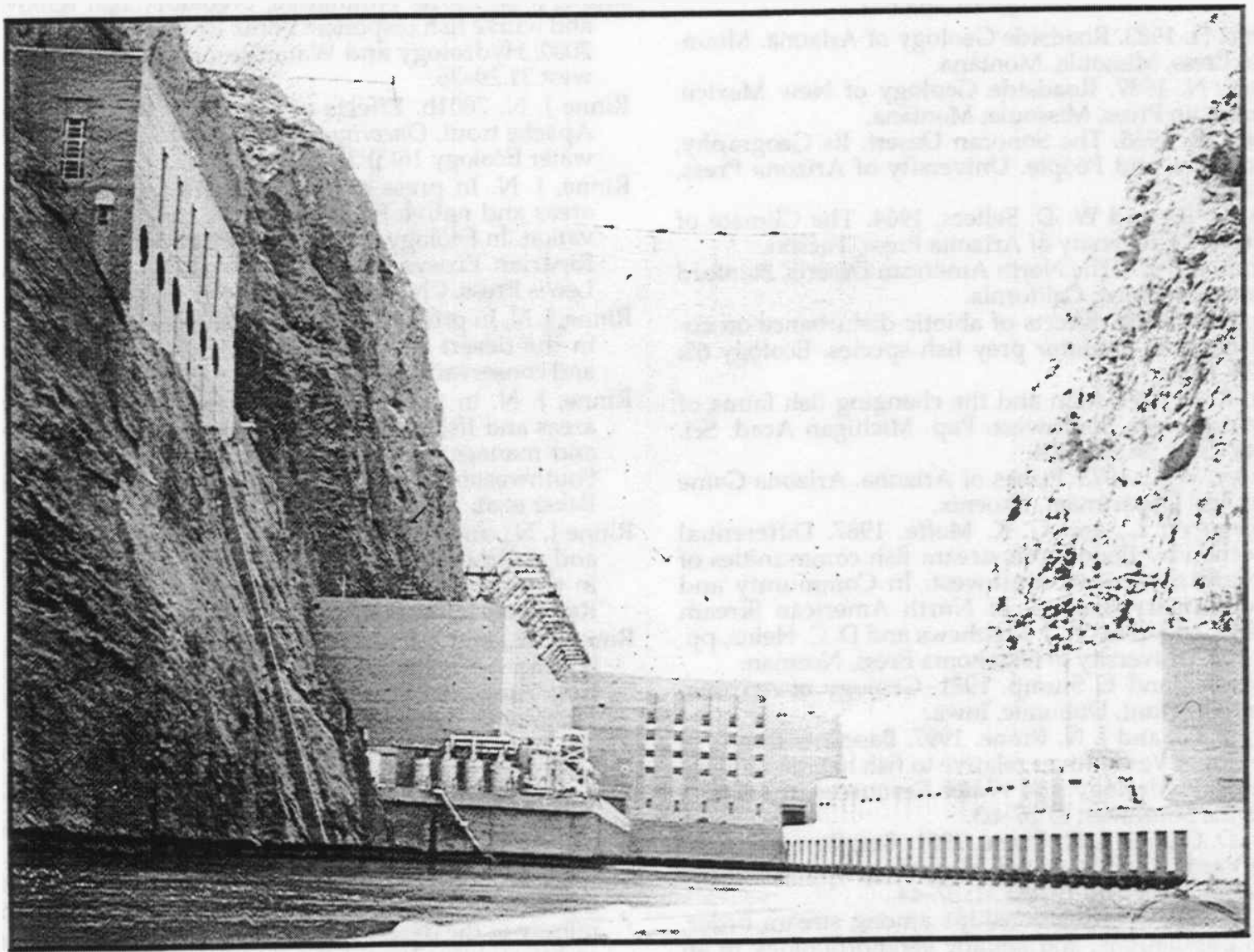

Figure 4. Large mainstream dams such as Hoover or Boulder Dam on the Colorado River dramatically alter flow regimes, water quality, and fish assemblages in major southwestern rivers.

species diversity in aquatic habitats. These transplanted, nonnative species in reservoir habitats soon moved up and downstream into lotic or riverine habitats where native species yet persisted. In a period of 25 to 50 years, many species have become much reduced in numbers, listed as federally threatened or endangered, or extirpated in some reaches of rivers. Two native fishes in Arizona are now extinct (Rinne in press a). Several large river species such as Colorado pikeminnow (Ptyocheilus lucius) and razorback sucker (Xyrauchen texanus) once migrated for spawning up these river systems. Mainstream dams precluded such migrations and these species became extirpated from the Gila River Basin within 50 years.

\section{CONCLUSIONS AND MANAGEMENT IMPLICATIONS}

Natural hydrology and geomorphology have been keystone factors in delimiting and sustaining native fish distribution and abundance in southwestern rivers and streams. The marked alteration of natural hydrologic regimes has been devastating to native fishes. These changes coupled with introduction of nonnative fish species have resulted in the fish fauna of the Southwest being largely listed as threatened and endangered. Sustaining native southwestern fishes will necessitate a focus on maintaining reaches of river that still contain native fish assemblages. That is, respective river reaches need to be designated as "native management reaches" (Rinne in press a). Normally these are headwater reaches above dams, diversions, and extensive groundwater removal areas. On the other hand, more downstream reaches with their predominance of nonnative species should be designated as nonnative, or sport fishing reaches. The two groups of fish species are like oil and waterone cannot mix them and hope for a favorable solution. 


\section{LITERATURE CITED}

Chronic, H. 1983. Roadside Geology of Arizona. Mountain Press, Missoula, Montana.

Chronic, N. 1987. Roadside Geology of New Mexico. Mountain Press, Missoula, Montana.

Dunbier, R. 1968. The Sonoran Desert. Its Geography, Economy, and People. University of Arizona Press, Tucson.

Green, G. R., and W. D. Sellers. 1964. The Climate of Arizona. University of Arizona Press, Tucson.

Jaeger, E. C. 1957. The North American Deserts. Stanford University Press, California.

Meffe, G. K. 1984. Effects of abiotic disturbance on coexistence of predator prey fish species. Ecology 65: 1525-1534.

Miller, R. R. 1961. Man and the changing fish fauna of the American Southwest. Pap. Michigan Acad. Sci. Arts. Letts. 46:365-404.

Minckley, W. L. 1973. Fishes of Arizona. Arizona Game and Fish Department, Phoenix.

Minckley, W. L., and G. K. Meffe. 1987. Differential selection by flooding in stream fish communities of the arid American southwest. In Community and Evolutionary Ecology of North American Stream Fishes, edited by W. . . Matthews and D. C. Heins, pp. 93-104. University of Oklahoma Press, Norman.

Nations, D., and E. Stump. 1981. Geology of Arizona. Kendall/Hunt, Dubuque, Iowa.

Neary, D. G., and J. N. Rinne. 1997. Baseflow trends in the upper Verde River relative to fish habitat requirements. Hydrology and Water Resources in Arizona and the Southwest 27:57-63.

Neary, D. G., and J. N. Rinne. 2001. Baseflow trends in the Verde River revisited. Hydrology and Water Resources of the Southwest 31: 37-44.

Platts, W. S. 1979. Relationships among stream order, fish populations, and aquatic geomorphology in an Idaho river drainage. Fisheries 4(2):5-9.

Rea, A. M. 1983. Once a River: Bird Life and Habitat Changes on the Middle Gila. University of Arizona Press, Tucson.

Rinne J. N. 1994. Declining southwestern aquatic habitats and fishes: Are they sustainable? Sustainability symposium, USDA Forest Service, General Technical Report RM-247:256-265. Flagstaff, Arizona.

Rinne J. N. 1995. Interactions of predation and hydrology on native southwestern fishes: Little Colorado spinedace in Nutrioso Creek, Arizona. Hydrology and Water Resources in Arizona and the Southwest 22-25:33-38.

Rinne, J. N. 1996. The effects of introduced fishes on native fishes: Arizona, southwestern United States. In Protection of Aquatic Diversity, Proceedings of the World Fisheries Conference, Theme 3, edited by D. P. Philipp, pp. 149-159. Oxford and IBH, New Delhi.

Rinne, J. N. 1999. The status of spikedace, Meda fulgida, in the Verde River, 1999. Implications for research and management. Hydrology and Water Resources in the Southwest 29:57-64.

Rinne, J. N. 2000. Fish and grazing relationships in southwestern United States. In Ecological and Socioeconomic Aspects of Livestock Management in the Southwest, edited by R. Jamison, C. Raish, and D. Finch. Elsevier, Amsterdam.
Rinne, J. N. 2001a. Nonnative, predatory fish removal and native fish response: Verde River, Arizona, 19992000. Hydrology and Water Resources of the Southwest 31:29-36.

Rinne J. N. 2001b. Effects of substrate composition on Apache trout, Oncorhynchus apache. Journal of Freshwater Ecology 16(3):355-365.

Rinne, J. N. In press a. Southwestern riparian-stream areas and native fishes: Status, threats, and conservation. In Ecology and Management of Southwestern Riparian Ecosystems, edited by M. B. Baker et al. Lewis Press. Chicago.

Rinne, J. N. In press b. Native-nonnative fish interactions in the desert Southwest: Lessons for management and conservation. Intermountain Journal of Science.

Rinne, J. N. in press c. Southwestern riparian-stream areas and fish habitat: Implications for conservation and management. In Ecology and Management of Southwestern Riparian Ecosystems, edited by M. B. Baker et al.

Rinne J. N., and B. P. Deason. 2000. Habitat availability and utilization by two native, threatened fish species in two southwestern rivers. Hydrology and Water Resources in the Southwest 30:43-52.

Rinne J. N., and J. Janish. 1995. Coldwater fish stocking and native fishes in Arizona: Past, present and future. American Fisheries Society Special Publication 15:397-406. Bethesda, Maryland.

Rinne, J. N., and W. L. Minckley. 1991. Native fishes in arid lands: Dwindling resources of the desert Southwest. USDA Forest Service Gen. Tech. Rep. RM-206. Rocky Mountain Forest and Range Experimental Station, Fort Collins, Colorado.

Rinne, J. N., and J. A. Stefferud. 1997. Factors contributing to collapse yet maintenance of a native fish community in the desert Southwest (USA). In Developing and Sustaining World Fisheries Resources: The State of Science and Management, edited by D. A. Hancock, D. C. Smith, A. Grant, and J. P. Beaumer, pp. 157-162. Second World Fish Congress, Brisbane, Australia, July 28-August 2, 1996.

Rinne J. N., J.A. Stefferud, A. Clark, and P. Sponholtz. 1998. Fish community structure in the Verde River Arizona, 1975-1997. Hydrology and Water Resources in Arizona and the Southwest 28:75-80.

Rinne, J. N., B. Holand, and G. Sundnes. 2002. Comparison of heart rate in fishes: Cold, temperate sea water versus warm, desert rivers. Proceedings of the 5 th International Congress on Fish Biology, Vancouver, British Columbia, July 21-26.

Rinne J. N., P. Boucher, D. Miller, A. Telles, J. Montzingo, R. Pope, B. Deason, C. Gatton, and B. Merhage. In press. Comparative fish community structure in two southwestern desert rivers. In Restoring Native Fish to the Lower Colorado River: Interactions of Native and Non-Native Fishes: A Symposium and Workshop, edited by S. Leon, P. Stine, and C. Springer.

Wirt, L., and H. W. Hjalmarson. 2000. Sources of springs supplying base flow to the Verde River headwaters, Yavapai County, Arizona. U.S. Geological Survey Open File Report 99-0378. 